\section{The Heritage Issue in India}

\section{Dr Sukanya Sharma ${ }^{\dagger}$}

Anything that is more than 100 years old is declared as heritage in India under the Ancient Monuments and Archaeological Sites and Remains Act, 1958. Under the provision of this act, giving a two months' notice, the central government can declare a monument or an archaeological site and remains to be of national importance. A copy of every such notification is affixed in a conspicuous place near the monument or site; and remains and any person interested in any such ancient monument or archaeological site and remains may, within two months after the issue of the notification, object to the declaration of the monument, or the archaeological site and remains, to be of national importance. On the expiry of the said period of two months, the Central Government may, after considering the objections, if any, received by it, declare by notification in the Official Gazette, the ancient monument or the archaeological site and remains, as of national importance. After this, the ancient monument or the archaeological site and remains become the property of the state.

The act further states that where there is no known owner of the site, monument or the material the Director General, Archaeological Survey of India, becomes the owner. Where the owner is present he or she has to enter into an agreement with the central government in which it is stated that the owner cannot use the monument for any purpose, cannot remove, destroy or alter any part of the monument, cannot build on or near the site or monument.

The moral of the story is the owner loses all rights over the monument or object. For this reason, nobody in India is ready to declare

\footnotetext{
${ }^{\dagger}$ Associate Professor, Department of Humanities and Social Sciences,

Indian Institute of Technology, Guwahati, Emails:
} sukanyasharma2013@gmail.com; sukanya@iitg.ernet.in anything, be it a house, ornaments or utensils as more than 100 years old. Whatever the government has declared as heritage are sites or items people do not require in their day to day life. If a temple is declared as a heritage monument, it enhances the reputation of the place or community and as the act allows customary observances to continue people are not affected. It is managed by outdated colonial laws for which we cannot relate with what is called 'our heritage' in India today. With intangible cultural heritage we are fine, but with the tangible, we are unsure what to do about it. They are all over the place, and the ideas of bracketing it as 'heritage' do not really appeal to us. We ignore it and leave to be somebody else's burden.

The primary objective of policies concerning heritage in India is conservation. However, most of the time, these structures are well known 'elite' monuments. Lesser known monuments or structures like old houses, pavements, walls, alleys, etc. which is still being used and occupied is rarely considered for conservation. As a result, they are renovated or removed as and when required obliterating vital information about past urban structures. Maybe each of these structures cannot be saved for practical reasons like the development pressure on land and space. However, at least they can be documented before they are destroyed or replaced and if possible a part of it can be sampled for posterity. There should be an act which advocates for compatibility of urban heritage management programmes with development programmes. There should be a policy for management of heritage as a cultural resource in India.

India has mainly three Acts which is for protection of the archaeological resources. They are (i) Ancient Monuments and Archaeological Sites and Remains Act, 1958; (ii) The Antiquities and Art Treasures Act, 1972; (iii) The Ancient Monuments and Archaeological (C) 2018 Sharma. This is an Open Access article distributed under the terms of the Creative Commons Attribution License (http://creativecommons.org/licenses/by/2.0), which permits unrestricted use, distribution, and reproduction in any medium, provided the original work is properly cited. 
Sites and Remains (Amendment and Validation) Act, 2010. However, these acts are not equipped to save heritage structures from real estate development, infrastructural developments, etc. What we need is an act like the National Historic Preservation Act of USA. This act balanced heritage protection with economic needs of the community and private landowners. In India once a property is declared as a heritage monument the umbilical cord that connects it with its surroundings is cut. It is fenced, locked with warnings that trespassers will be prosecuted under the law. As a result, many of these structures suffocate and die and 'lamenting the loss' becomes the introduction to all public displays of patriotism, identity movements, etc.

The National Historic Preservation Act (NHPA) of America, formulated in 1966 enforces historic preservation as a national policy in the USA. National Register of Historic Places (NRHP), a provision created under this act includes state resources and resources of local significance. It now includes nearly 1.4 million properties in 79,000 listings nominated by citizens nationwide. Two thirds (67\%) of the properties listed in the National Register hold their significance to local citizens and local history in addition to properties of national significance and almost half of these properties are privately owned. There is hardly a city or town throughout the USA without a property listed in the National Register of Historic Places. In India, the National Monuments Authority (NMA) under the Ministry of Culture, Govt. of India was set up in March 2010. In the list of recorded sites on the World Heritage, there are 759 cultural sites listed from India. In the Archaeological Survey of India webpage, there is an alphabetical list of State Protected Monuments which is rarely upgraded. Some of these sites are difficult to trace, and there is no move made every year to review or upgrade the list. The National Register of Historic Places in the USA has grown substantially since it was implemented in 1966. Every year new nominations are received. Property owners who deemed their property fit to be declared as a monument of historical importance and fulfil the four basic criteria's, fill up a standard nomination form and provide the necessary information about the property. The owners might employ historians and historic preservation consultants. They will receive tax incentives to promote the preservation of income-producing historic properties. The four criteria's are, the property must make a contribution to the significant pattern of American history, is associated with significant people of the American past, concerns the distinctive characteristics of the building by its architecture and construction, including having great artistic value or being the work of a master, is satisfied if the property has yielded or may be likely to yield information relevant to prehistory or history. The properties and sites listed in the Register, as well as those located in and contributing to the period of significance of National Register Historic Districts, become eligible for the federal tax benefits.

Owners of income-producing properties listed individually in the National Register of Historic Places or of properties that are contributing resources within a National Register Historic District may be eligible for a $20 \%$ investment tax credit for the rehabilitation of the historic structure. The rehabilitation may be of a commercial, industrial, or residential property, for rentals. Besides the $20 \%$ tax credit, the tax incentive programme offers a $10 \%$ tax credit for rehabilitation to owners of non historic, nonresidential buildings constructed before 1936 . Some properties may qualify for grants too for maintenance and upkeep of the properties.

This attractive incentive can be called the driving force behind the success of the National Historic Preservation Act (NHPA). In India, the fear is that this might lead to a massive loss in revenue generated by property tax as by adopting dubious means people might list undeserving properties and avail tax benefits without contributing much to the building of Indian history. However, at the same time as because monuments belonging to 'minor histories' are not being listed they are being destroyed at will, converting landscapes to unrecognisable entities after 50 or 200 years. 
As a result, memories, stories, fables, facts and events which connect the new generation with the past also get obliterated. Grandmas' stories even if told from real life experiences of just 50 or 100 years are just fantasies because there is no material evidence from the past to bridge the gap. Something as simple as the 'joint family system' does not appeal to the younger generation especially for the middle class because it is thought to be an expensive affair possible only for the rich and affordable. They have not seen the utilities of a central courtyard surrounded by the living quarters or of a kitchen with three dozen plates and six dozen bowls and tumblers.

Interpersonal relations are worsening with the gap between the past and the present widening. Like the 'organic' living the past is believed to be expensive. However, if the past is allowed to be managed as a resource by the people, maybe we will see better results. Maybe we can save the villages from the real estate developers. The Bengal Regulation XIX of 1810 is the first ever antiquarian legislation in India. It was to preserve buildings of historical and architectural value for the convenience of the public. What convenience it talked about we are not sure. Then came the Ancient Monuments Preservation Act of 1904, passed by Lord Curzon, the Viceroy of India followed by the three acts mentioned above. Except for the 1810 Bengal Regulation, there is no mention of the public or the people in these acts. Without the participation of the people, India's heritage is unlikely to be saved. There is a parallel discourse now that why taxpayers money in India should be used for conserving old buildings rather than building new flyovers or better sanitation facilities.

Maybe in today's India, we cannot go as public as America is in the context of heritage. For workers on heritage, it is Doldrums. The state has failed to save it, and the people are not eager to save it either. To come out of this doldrum can we have some guidelines for heritage management in India. The ideas like sampling heritage, salvage operations can be included in it to make the population aware that it is not necessary that all old building need to be preserved or the whole land surface strewn with ancient broken bricks need to be fenced. Maybe part of the building can be conserved. Incentives can be provided to the owners like regular maintenance by organisations with technical expertise free of cost. State-funded colleges, universities, mission headquarters or all other capable organisation can be asked to maintain all such properties within a particular radius. They can organise local citizen groups to monitor and work for the development of the heritage properties of the area. UNESCO adopted a recommendation on Historic Urban Landscape (HUL) on 10th November 2011 which embraces the policy, governance and management concerns including participating stakeholders, public and private partners who aim at integrating urban heritage conservation and social and economic development for the management of urban heritage. The approach uses tools like (i) civic engagement, (ii) knowledge and planning tools, (iii) regulatory systems, (iv) and financial tool for managing heritage resources.

For the implementation of the HUL citizens from all walks of life in an area can be encouraged to undertake ground reconnaissance surveys, photographic documentation, develop case studies, etc. to make this interaction with the heritage monuments more vibrant and dynamic. Reading through the history books and other literary sources for tracing the history of each of the monuments can be distributed as school level or graduate projects. Pencil drawing of the monuments and drawing the objects to scale for the thorough recording of the monuments, preparing inventories of the cultural resources of the area for heritage resource management are some of the other points which can be included in the policy guidelines. This interaction with the stakeholders will help to develop a dialogue, and more democratically a decision can be taken on which monument can be preserved and which can be documented and dismantled. 
This methodology will be both conventional and contemporary. Conserving the historic environment is not about "preventing change, but managing it. Preventing a change in landscape is impossible. The matter of concern is the speed at which landscapes are changing, leading to a loss of sense of place. Archaeological, historical or cultural heritage should be considered as a factor securing continuity in the development process, maintaining social integration and preventing the environment from becoming meaningless.

Communication between the government and the other stakeholders of the property should primarily focus on preserving as well sustainability. It should be a programme with long-term goals. Risk preparedness is another vital issue, essential for improving the capacity of cultural heritage managers to prepare better, respond to, and recover from disasters due to natural and human doings. Raising awareness and appreciation of the values of cultural heritage among community members must be attempted all over India. This might help us to develop a heritage management policy suitable for India per se. Borrowed ideas and methodologies from elsewhere may not work in the Indian context. 